\title{
Determination of the worst case for cleaning validation of equipment used in the radiopharmaceutical production of lyophilized reagents for ${ }^{99 \mathrm{~m}} \mathrm{Tc}$ labeling
}

\author{
Luciana Valéria Ferrari Machado Porto*, Neuza Taeko Okasaki Fukumori, Margareth Mie \\ Nakamura Matsuda
}

Radiopharmacy Center, Institute of Energetic and Nuclear Search, IPEN-CNEN/SP, São Paulo, São Paulo

\begin{abstract}
Cleaning validation, a requirement of the current Good Manufacturing Practices (cGMP) for Drugs, consists of documented evidence that cleaning procedures are capable of removing residues to predetermined acceptance levels. This report describes a strategy for the selection of the worst case product for the production of lyophilized reagents (LRs) for labeling with ${ }^{99 \mathrm{~m}} \mathrm{Tc}$ from the Instituto de Pesquisas Energéticas e Nucleares (IPEN-CNEN/São Paulo). The strategy is based on the calculation of a "worst case index" that incorporates information about drug solubility, cleaning difficulty, and occupancy rate in the production line. It allowed a reduction in the required number of validations considering the possible manufacturing flow of a given product and the subsequent flow, thus facilitating the process by reducing operation time and cost. The products identified as "worst case" were LRs PUL-TEC and MIBI-TEC.
\end{abstract}

Uniterms: Radiopharmaceuticals/production. Drugs/manufacturing/cleaning validation. Lyophilized reagents.

A validação de limpeza é uma exigência dos atuais regulamentos de Boas Práticas de Fabricação de Medicamentos (BPF) e consiste na evidência documentada, que demonstra que os procedimentos de limpeza removem os resíduos em níveis de aceitação pré-determinados. Este estudo apresenta uma estratégia para escolha do produto "pior caso" da linha de produção de reagentes liofilizados para marcação com $^{99 \mathrm{~m}}$ Tc do Instituto de Pesquisas Energéticas e Nucleares (IPEN-CNEN/São Paulo). A estratégia baseiase no cálculo de um índice denominado "índice para pior caso," que utiliza informações de solubilidade dos fármacos, dificuldade de limpeza dos equipamentos e ocupação dos produtos na linha de produção. A estratégia adotada proporcionou a diminuição no número de validações necessárias, considerando-se as possibilidades de sequências de fabricação de um determinado produto e do produto subsequente, possibilitando a simplificação do processo e redução no tempo e nos custos das atividades envolvidas. Os produtos indicados como pior caso foram os reagentes liofilizados (RL) PUL-TEC e MIBI-TEC.

Unitermos: Radiofármacos/produção. Medicamentos/fabricação/validação de limpeza. Reagentes liofilizados.

\section{INTRODUCTION}

Radiopharmaceuticals are defined as pharmaceutical preparations with diagnostic or therapeutic purposes, which when ready for use, contain one or more radionuclides (Brasil, 2009) and can be classified into four categories (World Health Organization, 1997): ready-

*Correspondence: L. V. F. M. Porto. Centro de Radiofarmácia. Instituto de Pesquisas Energéticas e Nucleares, IPEN-CNEN/SP. Avenida Prof. Lineu Prestes, 2242 - 05508-000 - São Paulo-SP, Brasil. E-mail: luciana.porto@anvisa.gov.br to-use radioactive products, radionuclide generators, non-radioactive components ["kits," lyophilized reagents (LR)] for the preparation of labeled compounds with a radioactive component (usually the eluate from a radionuclide generator), and precursors used for radiolabeling other substances (e.g., samples from patients) before administration.

Medicine manufacturers must assure that all applicable and necessary actions during the manufacturing are implemented, ensuring that their products comply with the required quality standard so that they can be 
put to their intended use. Therefore, the validation of the manufacturing process and all related activities, including equipment cleaning, ensures that safe and effective products are obtained (Brasil, 2010a).

Cleaning validation ensures that cleaning equipment procedures effectively remove existing residues (manufactured product residues, degradation products, conservatives, excipients, and/or cleaning agents) to a predetermined acceptance level. Thus, it is possible to guarantee that after the cleaning is performed, the next manufactured product will not contain substances from the previous process, i.e., there is no crosscontamination (Brasil, 2010a; Waghmare et al., 2013). Cross-contamination control plays an important role in maintaining the product quality (Pawar et al., 2011).

The validation of every cleaning process used in the pharmaceutical industry would be a slow procedure, with high cost and delayed results. If a pharmaceutical industry produces $n$ products, the number of possibilities for validating the cleaning equipment will be $n ! /(n-2) !$, where $n$ ! is the factorial number given by $\boldsymbol{n}(\boldsymbol{n}-\mathbf{1})(\boldsymbol{n}-\mathbf{2}) \ldots$ (3)(2)(1). Therefore, if an industry produces five products, the number of possible cleaning processes will be 120 (Alencar et al., 2006b).

According to the International Conference on Harmonization of Technical Requirements for Registration of Pharmaceuticals for Human Use (ICH) Q7A, if various active pharmaceutical ingredients or intermediates are manufactured in the same equipment and if the equipment is cleaned by the same process, it is acceptable to choose only one substance for cleaning validation. This selection, called worst case selection, should be based on the solubility and difficulty of cleaning, in addition to the calculation of maximum residue limits based on strength, toxicity, and stability (Food and Drug Administration, 2001). The same criterion is considered valid by the World Health Organization; there is no need for the individual validation of cleaning processes and the study of the worst case is acceptable, as long as the selected substance is that presenting the greatest cleaning difficulty (World Health Organization, 2007).

Thus, an abridgement of the validation of cleaning processes is accepted and consists of considering critical scenarios or worst cases among the products or processes that represent a similar group. In this case, the worst case will represent the cleaning of all equipment in the production line, under the assumption that, after approval and cleaning validation of the worst case, the processes used for other products will be considered validated as well.

Studies of worst cases in cleaning validation are rare. Some have been reported by Cleaning Validation Technologies (2001a, b, 2004), who presented interesting discussions of strategies for grouping products for cleaning validation and their advantages and disadvantages.

The purpose of the present study was to develop a strategy for worst case selection for cleaning validation of equipment used in radiopharmaceutical manufacture at the Nuclear and Energy Research Institute of the National Commission of Nuclear Energy (IPEN-CNEN/São Paulo), in particular of LRs for labeling with technetium $\left({ }^{99 \mathrm{~m}} \mathrm{Tc}\right)$, with the aim of reducing the number of cleaning validation possibilities. Only the production of nonradioactive components was considered.

\section{MATERIAL AND METHODS}

The calculation of a worst case index (WCI) was based on drug solubility, difficulty of equipment cleaning, and occupancy of products in the production line.

\section{Solubility factor $f_{S}$}

Solubility data for the drug substances used in the preparation of LRs were obtained mainly from chemical product information sheets, certificates of analysis containing specifications issued by the suppliers, in databases containing information about chemical products (Chemical Book, 2015; Chemspider, 2015; Pubchem, 2015), Material Safety Data Sheets (MSDS), and Merck Index (1996). For some drug substances, the information was not available as a number but sometimes as a solubility expression. The numbers and the solubility expressions were normalized based on the descriptive terms for solubility and numerical ranges defined in the Brazilian Pharmacopoeia (Brasil, 2010b). All numerical solubility data were converted to parts per million ( $\mathrm{ppm}$ ). Using a presumed classification for the different ranges of solubility, a table was created to assign a score, the solubility factor $f_{S}$, which was used in the calculation of WCI.

Table I details the scores assigned to the solubility factor $f_{S}$.

A higher $f_{S}$ was assigned to drugs with higher solubility and a lower $f_{S}$ to drugs with lower solubility.

\section{Cleaning difficulty factor $f_{D}$}

The factor $f_{D}$ was obtained from responses given during interviews with operators of the LR production area responsible for routine cleaning of equipment. A questionnaire with three response options was presented 
TABLE I - Solubility factor $f_{S}$

\begin{tabular}{lccc}
\hline Descriptive term & Solubility $(\mathbf{S})$ in water $(\mathbf{p p m})$ & Classification & Score $\boldsymbol{f}_{S}$ \\
\hline Highly soluble & $\mathrm{S}>1,000,000$ & & \\
Easily soluble & $100,000<\mathrm{S}<1,000,000$ & High solubility & 3 \\
Soluble & $33,000<\mathrm{S}<100,000$ & & \\
\hline Sparingly soluble & $10,000<\mathrm{S}<33,000$ & Moderate solubility & 2 \\
Slightly soluble & $1,000<\mathrm{S}<10,000$ & Low solubility & 1 \\
\hline Very slightly soluble & $100<\mathrm{S}<1,000$ & \\
Practically insoluble or insoluble & $\mathrm{S}<100$ & & \\
\hline
\end{tabular}

Source: adapted from Brasil (2010b).

to operators. A score based on cleaning difficulty was established, considering the production of all LR. Table II presents the scores assigned to the cleaning difficulty factor $f_{D}$.

TABLE II - Cleaning difficulty factor $f_{D}$

\begin{tabular}{cc}
\hline Score $-f_{D}$ & Cleaning difficulty \\
\hline 3 & Hard to clean \\
2 & Moderately difficult to clean \\
1 & Easy to clean \\
\hline
\end{tabular}

The score assigned to the $f_{D}$ and presented in Table II is related to the difficulty of cleaning the equipment and is directly proportional to the difficulty in performing cleaning procedures for a given product (LR).

The response of the most experienced operator was considered most important when a disagreement between responses was obtained.

\section{Occupation factor $f_{O}$}

To calculate $f_{o}$, typical data of lot numbers per year for each LR were obtained. The range of lot numbers was divided into five subranges and each received a score. The score corresponded to the occupation factor $f_{O}$ as described in Table III.

TABLE III - Occupation factor $f_{O}$

\begin{tabular}{cc}
\hline Score $-\boldsymbol{f}_{\boldsymbol{O}}$ & Quantity (lots/year) \\
\hline 5 & More than 50 lots \\
4 & $31-50$ lots \\
3 & $21-30$ lots \\
2 & $11-20$ lots \\
1 & Up to 10 lots \\
\hline
\end{tabular}

The factor $f_{O}$ is related to the use period of the production area by each LR. The selection of this factor was based on the number of cleaning procedures that need to be performed for each LR and in the probability of cross-contamination. There is a greater chance for a product manufactured more often to contaminate others than for products that are manufactured less frequently.

After the factors were defined, the WCI was calculated using equation 1 .

$$
\mathrm{WCI}=\frac{f_{0} \times f_{D}}{f_{S}}
$$

where: $f_{S}$ is the solubility factor of the drug in water expressed in ppm, $f_{D}$ is a factor that represents the difficulty of cleaning the equipment, and $f_{O}$ is the occupancy factor of the production line by a given drug

\section{RESULTS AND DISCUSSION}

The determination of the worst case for cleaning validation of the equipment used in the LR production area in IPEN was based on the work of Alencar, Clementino, and Neto (2006), which employed the strategy of selecting the worst case product in the Laboratório Farmacêutico do Estado de Pernambuco S/A-LAFEPE. It established an index incorporating information on toxicity, solubility, and difficulty of cleaning as well as the occupancy rate of each product in each unit of the laboratory. The factors were combined in a numerical index called Worst Case Index (WCI), and the magnitude of the index allowed the selection of the worst case product that should be used in cleaning validation. In the present study, toxicity data were not found for most of drug substances, so this parameter was not considered. The drugs used in the present study represented all the manufactured products in the LR production area at IPEN.

Usually, drug substance solubility's is expressed as functions of the amount of solvent required for 
solubilization of a given mass of solute, and for many compounds, solubility data are listed in pharmacopeias. However, the Brazilian Pharmacopoeia (Brasil, 2010b) and USP 38 (United States Pharmacopeia, 2015) lacked solubility information for the drug substances used in the production of LR for labeling with ${ }^{99 \mathrm{~m}} \mathrm{Tc}$. Accordingly, other sources were consulted, as described in Methods. Drug solubility has a high influence on the cleaning validation of equipment, given that the lower the water solubility, the higher the adhesion to the equipment and consequently, the more difficult the cleaning procedures, resulting in a higher contribution to the WCI index.

Some studies of methods for validation of equipment cleaning have been described (Alencar et al., 2004, 2006a; Andrade, 2012; Bago, 2010). Many industries seek a common denominator for grouping similar products, and by this process, they aim to turn a complex situation into a manageable project. Each industry has developed its own criteria and methodology for the selection of the worst case product (Agalloco, 1992). In the present study, solubility data, the difficulty of cleaning equipment, and the occupancy of the production line by the product were all used to determine the worst case for the cleaning validation of equipment used in the manufacture of radiopharmaceuticals-LR.

Solubility in water and references used in the calculation for their expression in ppm are shown in Table IV.

Table $\mathrm{V}$ shows lot numbers of LR manufactured in 2013 at IPEN/CNEN-SP.

The values of the factors $f_{S}, f_{D}$, and $f_{O}$ and the calculated value of the WCI index for each radiopharmaceutical are shown in Table VI. The WCI values of the products are shown in descending order.

The products PUL-TEC and MIBI-TEC showed the highest WCI index, with the same value of 3.0.

The WCI index of PUL-TEC can be attributed to its high solubility as well as difficulty in cleaning, in addition

TABLE IV - Solubility data for LR manufactured at IPEN-CNEN/SP

\begin{tabular}{|c|c|c|c|c|}
\hline Product - LR & Drug substance & $\begin{array}{l}\text { Water solubility } \\
\text { (per reference) }\end{array}$ & $\begin{array}{c}\text { Water solubility in ppm } \\
\text { (calculated) }\end{array}$ & Reference \\
\hline CIS-TEC & ethylenedicysteine & $4.712 \times 10^{5} \mathrm{mg} / \mathrm{L}$ & 471,200 & Chemspider \\
\hline DEX-500-TEC & dextran 500 & $* * *$ Soluble & & Pharmacosmos \\
\hline DEX-70-TEC & dextran 70 & $* * *$ Soluble & & Pharmacosmos \\
\hline DISI-TEC & disophenin & $52.751 \mathrm{mg} / \mathrm{L}$ & 52,751 & Chemspider \\
\hline DMSA-TEC & succimer & $2.88 \times 10^{5} \mathrm{mg} / \mathrm{mL}$ & $288,000,000$ & Pubchem \\
\hline DTPA-TEC & pentetic acid & $4.8 \mathrm{~g} / \mathrm{L}$ & 4,800 & Merck Index \\
\hline ECD-TEC & $\begin{array}{l}\text { ethylenedicysteine } \\
\text { diethyl ester } \\
\text { dihydrochloride }\end{array}$ & $* * *$ Soluble $\mathrm{H}_{2} \mathrm{O} / \mathrm{HCl}$ & & $\mathrm{ABX}$ \\
\hline FITA-TEC & phytic acid & Soluble & & Merck Index; Chemspider \\
\hline MDP-TEC & medronic acid & $50 \mathrm{mg} / \mathrm{mL}$ & 50,000 & Sigma-Aldrich \\
\hline MIBI-TEC & $\begin{array}{l}\text { copper tetraMIBI } \\
\text { tetrafluoroborate }\end{array}$ & $25 \mathrm{~g} / \mathrm{L}$ & 25,000 & $\begin{array}{l}\text { Lantheus Medical } \\
\text { Imaging }\end{array}$ \\
\hline PIRO-TEC & $\begin{array}{c}\text { sodium pyrophosphate } \\
\text { decahydrate }\end{array}$ & $\begin{array}{l}8.14 \mathrm{~g} / 100 \mathrm{~mL} \\
\text { Soluble }\end{array}$ & 81,400 & Merck Index; Chemspider \\
\hline PUL-TEC & *human albumin & **50 mg/mL & 50,000 & $\begin{array}{l}* * \text { Sigma-Aldrich human } \\
\text { albumin } 30 \% \text { solution }\end{array}$ \\
\hline *SAH-TEC & *human albumin & $* * 50 \mathrm{mg} / \mathrm{mL}$ & 50,000 & $\begin{array}{l}* \text { * Sigma-Aldrich human } \\
\text { albumin } 30 \% \text { solution }\end{array}$ \\
\hline TIN-TEC & tin(II) fluoride & $\begin{array}{c}\text { Soluble } \\
10^{6} \mathrm{mg} / \mathrm{L}\end{array}$ & $1,000,000$ & Merck Index; Chemspider \\
\hline
\end{tabular}

* During the manufacturing of LR SAH-TEC and PUL-TEC, the drug product Human Albumin 20\% solution (Grifols) is used as the active ingredient. Its solubility is not available in the Certificate of Analysis issued by the manufacturer. Solubility data were not found in any other source. ** Solubility of Human Albumin 30\% Solution (Sigma-Aldrich) was used. *** A numeric reference value of solubility was not found for the drugs ethylenedicysteine, diethyl ester dihydrochloride, dextran 70, and dextran 500 . 
TABLE V - Lot numbers of LR manufactured at IPEN-CNEN/ São Paulo in 2013

\begin{tabular}{lcc}
\hline Product & Drug substance & $\begin{array}{c}\text { Lot } \\
\text { numbers }\end{array}$ \\
\hline CIS-TEC & ethylenedicysteine & 12 \\
DEX-500-TEC & dextran 500 & 11 \\
DEX-70-TEC & dextran 70 & 11 \\
DISI-TEC & disophenin & 11 \\
DMSA-TEC & succimer & 17 \\
DTPA-TEC & pentetic acid & 23 \\
ECD-TEC & ethylenedicysteine & 15 \\
FITA-TEC & phytic acid & 15 \\
MDP-TEC & medronic acid & 53 \\
MIBI-TEC & copper tetraMIBI tetrafluoroborate & 25 \\
PIRO-TEC & sodium pyrophosphate & 19 \\
& decahydrate & \\
PUL-TEC & human albumin & 26 \\
SAH-TEC & human albumin & 6 \\
TIN-TEC & tin(II) fluoride & 9 \\
\hline
\end{tabular}

TABLE VI - Values of factors $f_{O}, f_{D}, f_{S}$ and WCI calculation for each LR manufactured at IPEN-CNEN/São Paulo

\begin{tabular}{lcccc}
\hline Product & $\boldsymbol{f}_{\boldsymbol{o}}$ & $\boldsymbol{f}_{\boldsymbol{D}}$ & $\boldsymbol{f}_{\boldsymbol{S}}$ & WCI \\
\hline PUL-TEC & 3 & 3 & $3^{*}$ & 3 \\
MIBI-TEC & 3 & 2 & 2 & 3 \\
MDP-TEC & 5 & 1 & 2 & 2.5 \\
DISI-TEC & 2 & 1 & 1 & 2.0 \\
DEX-500-TEC & 2 & 3 & 3 & 2.0 \\
DTPA-TEC & 3 & 1 & 2 & 1.5 \\
DEX-70-TEC & 2 & 2 & 3 & 1.33 \\
DMSA-TEC & 2 & 2 & 3 & 1.33 \\
FITA-TEC & 2 & 2 & 3 & 1.33 \\
SAH-TEC & 1 & 2 & $3 *$ & 0.66 \\
CIS-TEC & 2 & 1 & 3 & 0.66 \\
PIRO-TEC & 2 & 1 & 3 & 0.66 \\
ECD-TEC & 2 & 1 & 3 & 0.66 \\
TIN-TEC & 1 & 1 & 3 & 0.33 \\
\hline
\end{tabular}

* The solubility factor $f_{S}$ used in the WCI calculation was obtained with Human Albumin 30\% Solution (Sigma-Aldrich) data.

to an intermediate occupancy rate ( $>20$ lots), according to the operator's experience.

A few considerations apply to the WCI index of
PUL-TEC: aspects of the production process and albumin characteristics. These may explain the discrepancy between the high solubility attributed to the drug and the high cleaning difficulty reported by the operators. Albumin is the most abundant plasma protein and is a small molecule relative to other proteins. It is formed as a 584 amino acid chain with a molecular weight of approximately 69,000 Daltons (Cuppari, 2004).

Proteins are complex macromolecules formed of amino acid polymers and have four different structure levels: primary, secondary, tertiary, and quaternary. Although the sequence of amino acids corresponds to the primary protein structure, the chemical and biological properties are highly dependent on the three-dimensional or tertiary structure (Food Ingredients Brasil, 2012; Particle Sciences, 2009). Proteins can be classified by solubility, composition, function, shape, and size. Classification based on solubility and composition divides proteins into three main groups: simple, conjugated, and derived proteins. After hydrolysis, simple proteins yield only amino acids. and they coagulate upon heat treatment. Albumins are classified as simple proteins and the main property differentiating them from all other proteins is water solubility (Food Ingredients Brasil, 2012). Masuelli (2013) reported that albumin solubility is due to its high total electric charge and consequent strong hydrophilic ability. At $\mathrm{pH}$ close to neutrality, albumins are highly soluble in water: to $35 \%$ by weight in diluted saline solutions and to $50 \%$ by weight in pure water (Masuelli, 2013).

Several agents can change protein structure: for example, heating. This phenomenon is known as protein denaturation and consists of the breakdown of protein secondary and tertiary structures. As a result of denaturation, there is a change in the protein form, with a breaking of hydrogen bonds (responsible for the stability of protein conformation) and a consequent unraveling of peptide chains, which stretches them. This event causes a decrease in solubility and an increase in viscosity (Food Ingredients Brasil, 2012). During the manufacturing process of PUL-TEC, human albumin is heated to $100^{\circ} \mathrm{C}$, leading to denaturation, decreased solubility, and increased viscosity. This process explains the discrepancies in the information obtained for the calculation of the WCI index for PUL-TEC. Another factor that contributes to the solubility decrease and the viscosity increase is the use of sodium hydroxide $(\mathrm{NaOH})$, a strong base, during the PUL-TEC manufacturing process.

For the product MIBI-TEC, which also showed an intermediate occupancy rate, the intermediate cleaning difficulty and particularly the moderate solubility influenced the calculated WCI index of 3.0. 
The product MDP-TEC showed a WCI (2.5) similar to those of MIBI-TEC and PUL-TEC, with moderate solubility, ease of cleaning, and high occupancy factor (highest among the LR), as reflected in the WCI.

The WCI index calculated for DISI-TEC and DEX-500-TEC was the same (2.0), and both presented the same relatively low occupancy factor (11 lots). For DISI-TEC, easy cleaning and low solubility influenced the WCI, whereas the high solubility of DEX-500-TEC was highly influential in the WCI calculation. Even though the cleaning operators rated DEX-500-TEC as a product causing difficulty in cleaning, the Pharmacosmos company specializing in dextran synthesis points out that dextran fractions are highly soluble in water and electrolyte solutions and form clear and stable solutions (Pharmacosmos, 2015). They may form turbid solutions (during rest) when concentrated solutions of dextran fractions of low molecular weight $(5,000$ and 10,000$)$ are used.

The products DEX-70-TEC, DMSA-TEC, and FITA-TEC showed the same WCI value (1.33), close to the result obtained for DTPA-TEC. High solubility, moderate cleaning difficulty, and relatively low occupancy factor influenced the calculation.

The products SAH-TEC, CIS-TEC, PIRO-TEC, and ECD-TEC showed the same WCI index (0.66), distinct from that of PUL-TEC and MIBI-TEC. The high solubility of these four products and the low occupancy rate (the lowest among all products) of the first product were decisive factors in WCI determination. The product with the lowest WCI was TIN-TEC.

With the identification of products with the highest WCI indexes, the Radiopharmacy Center of IPEN-CNEN/ SP now has, in the products PUL-TEC and MIBI-TEC, a potential reference for the validation of the cleaning procedures of LR production equipment.

\section{CONCLUSION}

The starting point for a cleaning validation is an analysis of the critical situations or worst cases among the products or production processes that represent a similar group. That are guidelines showing it is preferable to use toxicological data. In the case of radiopharmaceuticals, the acquisition of these data was challenging because the active ingredient is either a radioactive material or a material that is not commonly used in the conventional pharmaceutical industry, so that such data are largely unavailable.

One of the main features of cleaning validation involves studies of the pharmaceutical previously produced and the product subsequently manufactured in the cleaned equipment. Considering that the LR radiopharmaceutical production area produces 14 LRs, there are several possible product sequences to be evaluated. The present study determined the two worst cases among $14 \mathrm{LR}$ for cleaning validation of the production equipment, representing an $85.7 \%$ reduction in the number of cleaning validation procedures.

The results obtained in this study showed that the worst case approach for cleaning validation, based on the calculation of an index that accounts for critical process parameters, is a simple and effective way to reduce the complexity and time requirement of the validation process, besides providing a way to reduce the cost of these activities.

\section{ACKNOWLEDGEMENTS}

The authors are grateful to the Radiopharmacy Center and its staff for the opportunity to design this study.

\section{REFERENCES}

AGALLOCO, J. "Points to Consider" in the validation of equipment cleaning procedures. J. Parenter. Sci. Technol., v.46, n.5, p.163-168, 1992.

ALENCAR, J.R.B.; CLEMENTINO, M.R.A.; ROLIM NETO, P.J. Validação da limpeza de equipamentos numa indústria de medicamentos: estratégia para escolha do "pior caso". Rev. Bras. Farm., v.87, n.1, p.13-18, 2006.

ALENCAR, J.R.B.; JIMENEZ, R.C.C.; LIMA, L.G.; ROLIM NETO, P.J.; OLIVEIRA, A.T.C.; OLIVEIRA, M.A.O.; RAMOS, S.V.V.; SANTOS, R. Validação de limpeza de equipamentos multipropósito para formas farmacêuticas líquidas: estudo de caso da zidovudina xarope. Acta Farm. Bonaerense, v.25, n.1, p.35-42, 2006.

ALENCAR, J.R.B.; MACHADO, L.B.; MEDEIROS, F.P.M.; MONTEIRO, D.B.; ROLIM NETO, P.J.; OLIVEIRA, A.T.C.; RAMOS, S.V.V. Validação de limpeza de zidovudina: estratégia aplicada ao processo de fabricação de medicamentos anti-retrovirais. Braz. J. Pharm. Sci., v.40, n.1, p.1-8, 2004.

ANDRADE, S.C.I. Validação de limpeza de equipamentos farmacêticos. Leiria, 2012. 124 p. [Dissertation of Master Degree. Instituto Politécnico de Leiria, EscolaSuperior de Turismo e Tecnologia do Mar0. 
BAGO, B.C. Validação do processo de limpeza de tanque multiuso utilizado para formulação de vacinas. Rio de Janeiro, 2010. 117 p. [Dissertation of Master Degree. Instituto de Química, Universidade do Estado do Rio de Janeiro].

BRASIL. Agência Nacional de Vigilância Sanitária. Resolução $R D C$ n.64, 18 de dezembro de 2009. Esta resolução possui o objetivo de estabelecer os requisitos mínimos para o registro de radiofármacos no país visando garantir a qualidade, segurança e eficácia destes medicamentos. Available at: $<$ http://portal.anvisa.gov.br/documents/33880/2568070/ res0064_18_12_2009.pdf/fa624c8f-f395-4394-84cd8c0f3918e9f9>. Accessed on: 29 Jun. 2015.

BRASIL. Agência Nacional de Vigilância Sanitária. Resolução $R D C$ n.17, 16 de abril de 2010. Esta resolução possui o objetivo de estabelecer os requisitos mínimos a serem seguidos na fabricação de medicamentos para padronizar a verificação do cumprimento das Boas Práticas de Fabricação de Medicamentos (BPF) de uso humano durante as inspeções sanitárias. Diário Oficial da União, Brasília, n.73, 19 abr. 2010. Section 1, p.94-110.

BRASIL. Agência Nacional de Vigilância Sanitária. Resolução da Diretoria Colegiada - RDC n.49, de 23 de novembro de 2010. In: FARMACOPEIA Brasileira. 5.ed. Brasília: Anvisa, 2010. v.1. Available at: <http://www.anvisa.gov. br/hotsite/cd_farmacopeia/pdf/volume1.pdf. Access in: Jun. 29, 2015.

BRASIL. Agência Nacional de Vigilância Sanitária. Validação de limpeza para farmoquímicas. Brasília: Anvisa, 2013. 28 p. Available at: <http://portal.anvisa.gov.br/ documents/33836/2501339/Guia+de+valida $\%$ C3\%A7\% $\mathrm{C} 3 \% \mathrm{~A} 3 \mathrm{o}+$ de + limpeza + para + farmoqu $\% \mathrm{C} 3 \% \mathrm{ADmicas} / 57$ 3873c0-f41c-42bd-833f-d01f5767ceb>. Accessed on: 29 Jun. 2015.

CHEMICAL Book: database. Drug solubility. Available at: $<$ http://www.chemicalbook.com/CASDetailList_19500_ EN.htm>. Accessed on: 01 Jun. 2015.

CHEMSPIDER: database by Royal Society of Chemistry. Disophenin. Available at: <http://www.chemspider.com>. Accessed on: 01 Jun. 2015.

CHEMSPIDER: database by Royal Society of Chemistry. Ethylenedicysteine. Available at: $<$ http://www.chemspider. com>. Accessed on: 01 Jun. 2015.
CHEMSPIDER: database by Royal Society of Chemistry. Phytic acid. Available at: < http://www.chemspider.com.> Accessed on: 01 Jun. 2015.

CHEMSPIDER: database by Royal Society of Chemistry. Sodium pyrophosphate. Available at: <http://www. chemspider.com $>$. Accessed on: 01 Jun. 2015.

CHEMSPIDER: database by Royal Society of Chemistry. Tin(II) fluoride. Available at: <http://www.chemspider. com $>$. Accessed on: 01 Jun. 2015.

CLEANING VALIDATION TECHNOLOGIES. Equipment grouping strategies for cleaning validation: cleaning memo for August 2001. 2001a. 2 p. Available at: <http://www. cleaningvalidation.com/files/98739147.pdf $>$. Accessed on: 28 Jun. 2015.

CleAning VAlidation TECHNOLOGIES. Product grouping strategies for cleaning validation: cleaning memo for July 2001.2001b. 3 p. Available at: <http://www. cleaningvalidation.com/files/98739154.pdf>. Accessed on: 28 Jun. 2015.

CLEANING VALIDATION TECHNOLOGIES. Selecting worst-case products for grouping: cleaning memo for October 2004. 2004. 2 p. Available at: <http://www. cleaningvalidation.com/files/98736413.pdf $>$. Accessed on: 28 Jun. 2015.

CUPPARI, L.; DRAIBE, S.A.; KAMIMURA, M.A.; SANTOS, N.S.J. Albumina sérica como marcador nutricional de pacientes em hemodiálise. Rev. Nutr., v.17, n.3, p.339-349, 2004.

FOOD AND DRUG ADMNISTRATION. Guidance for industry, Q7A good manufacturing practice guidance for active pharmaceutical ingredients. August, 2001. Available at: <http://www.fda.gov/ICECI/ComplianceManuals/ CompliancePolicyGuidanceManual/ucm200364.htm>. Accessed on: 01 Jun. 2015.

FOOD INGREDIENTS BRASIL. Dossiê proteínas: proteínas. Food Ingredients Brasil, n.22, p.60-72, 2012.

MASUELLI, M.A. Study of bovine serum albumin solubility in aqueous solutions by intrinsic viscosity measurements. $A d v$. Phys. Chem., v.2013, art.ID360239, p.1-8, 2013. 
MERCK Index: an encyclopedia of chemicals, drugs, and biologicals. 12.ed. Whitehouse Station: Merck, 1996. $1741 \mathrm{p}$.

PARTICLE SCIENCES. Protein structure. Bethlehem: Particle Science, 2009. 2 p. (Technical Brief 2009, v.8). Available at: $<$ http://www.particlesciences.com/docs/technical_briefs/ TB_8.pdf $>$. Accessed on: 01 Jun. 2015.

PAWAR, H.A.; BANERJEE, N.D.; PAWAR, S.; PAWAR, P. Current perspectives on cleaning validation in pharmaceutical industry: a scientific and risk based approach. Int. J. Pharm. Phytopharmacol. Res., v.1, n.1, p.8-16, 2011.

PHARMACOSMOS: database by Dextran Chemistry. Dextran 500. Available at: $<\mathrm{http}: / / \mathrm{ww} w . d e x t r a n . n e t / a b o u t-d e x t r a n /$ dextran-chemistry.aspx $>$. Accessed on: 01 Jun. 2015.

PHARMACOSMOS: database by Dextran Chemistry. Dextran 70. Available at: <http://www.dextran.net/ about-dextran/ dextran-chemistry.aspx $>$. Accessed on: 01 Jun. 2015.
PUBCHEM Compound: database by The National Center for Biotechnology Information. Succimer. Available at: $<\mathrm{http}: / /$ www.ncbi.nlm.nih.gov/pccompound $>$. Accessed on: 01 Jun. 2015.

RODRICKS, J.V. Risk assessment at hazardous waste disposal sites. Hazardous Waste, v.1, n.3, p.333-362, 1984.

UNITED States Pharmacopeia. USP 38. National Formulary: NF 33. Rockville: The United States Pharmacopeial Convention, 2015.

WAGHMARE, P.V.; CHINCHOLE, A.S.; POUL, B.N.; BHUSNURE, O.G. A brief review on cleaning validation and its significance in pharmaceutical industry. Pharma Sci. Monit., v.4, n.4, p.165-192, 2013.

WORLD HEALTH ORGANIZATION. Quality assurance of pharmaceuticals: a compendium of guidelines and related materials. 2.ed. Geneva: WHO, 1997. v.2, 248 p.

Received for publication on $10^{\text {th }}$ August 2015 Accepted for publication on $5^{\text {th }}$ October 2015 